\title{
Pathophysiology of acute meningitis caused by Streptococcus pneumoniae and adjunctive therapy approaches
}

\author{
Fisiopatologia da meningite ocasionada pelo Streptococcus pneumoniae e novas \\ possibilidades terapêuticas adjuvantes
}

Tatiana Barichello', Jaqueline S. Generoso', Allan Collodel', Ana Paula Moreira', Sérgio Monteiro de Almeida²

\begin{abstract}
Pneumococcal meningitis is a life-threatening disease characterized by an acute purulent infection affecting piamater, arachnoid and the subarachnoid space. The intense inflammatory host's response is potentially fatal and contributes to the neurological sequelae. Streptococcus pneumoniae colonizes the nasopharynx, followed by bacteremia, microbial invasion and blood-brain barrier traversal. S. pneumoniae is recognized by antigen-presenting cells through the binding of Toll-like receptors inducing the activation of factor nuclear kappa B or mitogenactivated protein kinase pathways and subsequent up-regulation of lymphocyte populations and expression of numerous proteins involved in inflammation and immune response. Many brain cells can produce cytokines, chemokines and others pro-inflammatory molecules in response to bacteria stimuli, as consequence, polymorphonuclear are attracted, activated and released in large amounts of superoxide anion and nitric oxide, leading to the peroxynitrite formation, generating oxidative stress. This cascade leads to lipid peroxidation, mitochondrial damage, blood-brain barrier breakdown contributing to cell injury during pneumococcal meningitis.
\end{abstract}

Key words: Streptococcus pneumoniae, meningitis, cytokines, chemokines, oxidative stress.

RESUMO

A meningite pneumocócica é doença potencialmente fatal caracterizada por infecção aguda purulenta que afeta a pia-máter, a aracnoide e o espaço subaracnoide. A resposta inflamatória do hospedeiro é potencialmente fatal e contribui para as sequelas neurológicas. 0 processo inicia-se com a colonização da nasofaringe pelo Streptococcus pneumoniae, seguida de invasão, bacteremia e passagem através da barreira hematoencefálica. O S. pneumoniae é reconhecido por células apresentadoras de antígenos através da ligação aos receptores Toll-like. Isto induz a ativação do fator nuclear kappa B ou proteína quinase ativada por mitógenos. Muitas células cerebrais também podem produzir citocinas, quimiocinas e outras moléculas pró-inflamatórias em resposta aos estímulos bacterianos. Como consequência, são atraídos polimorfonucleares, ocorrendo a liberação de grandes quantidades de ânion superóxido e óxido nítrico, o que leva à formação de peroxinitrito e ocasiona o estresse oxidativo. Esta cascata pró-inflamatória leva à peroxidação lipídica, a danos mitocondriais e à ruptura da barreira hematoencefálica, contribuindo para o dano celular em meningite pneumocócica.

Palavras-Chave: Streptococcus pneumoniae, meningite, citocinas, quimiocinas, estresse oxidativo.

Bacterial meningitis is the most common and serious bacterial infection of the central nervous system (CNS), characterized by an acute purulent infection of the piamater, arachnoid and subarachnoid space ${ }^{1}$. Approximately 1.2 million cases are estimated to occur annually world-wide, resulting in 135,000 deaths ${ }^{2.3}$. Streptococcus pneumoniae and Neisseria meningitidis are the main etiologic agents responsible for most of the meningitis cases in Europe and in the USA with up to $61 \%$ of total cases ${ }^{1}$. In Brazil, in 2011, among all age groups according to the Sistema de Informação de Agravos de Notificação (SINAN) were confirmed 8,676 meningitis cases, from these $37 \%(n=3,194)$ were bacterial meningitis and $41 \%(n=3,562)$ were viral meningitis. Among all the bacterial meningitis cases $35 \%(n=1,133)$ were meningococcal; $43 \%$ $(n=1,383)$ were meningitis by other bacteria and $15 \%(n=487)$ by pneumococcus ${ }^{4}$.

\footnotetext{
${ }^{1}$ Laboratório de Microbiologia Experimental e Instituto Nacional de Ciência e Tecnologia Translacional em Medicina, Programa de Pós-Graduação em Ciências da Saúde, Universidade do Extremo Sul Catarinense, Criciúma SC, Brazil.

${ }^{2}$ Laboratório de Virologia, Hospital de Clínicas, Universidade Federal do Paraná e Instituto de Pesquisa Pelé Pequeno Príncipe, Curitiba PR, Brazil.

Correspondence: Tatiana Barichello; Laboratório de Microbiologia Experimental - Universidade do Extremo Sul Catarinense;Avenida Universitária, 1.105; 88806-000 Criciúma SC, Brasil; E-mail: tba@unesc.net

Support: This research was supported by grants from CNPq, FAPESC, UNESC, INCT-TM and L'Oréal-UNESCO Brazil Fellowship for Women in Science 2011. Conflict of interest: There is no conflict of interest to declare.

Received 02 January 2012; Received in final form 26 January 2012; Accepted 12 February 2012
} 
Pneumococcus is the most severe cause of bacterial meningitis resulting in a $20-30 \%$ of hospital mortality an up to a $40 \%$ rate of intracranial complications such as brain edema, hydrocephalus and intracranial hemorrhage ${ }^{1,5}$. Even patients with good apparent recovery may present sequelae; moreover, around one-third of the patients have cognitive impairments ${ }^{5}$. These impairments consist mainly of cognitive slowness, learning impairment, deafness, blindness, neuropsychiatric impairments, cerebral palsy, seizure disorders and mental retardation ${ }^{6}$. The objective of this paper was to review some aspects of the meningitis pathophysiology caused by $S$. pneumoniae and discuss some possible therapeutic adjunctive approaches.

\section{MECHANISMS OF BACTERIAL COLONIZATION}

The pneumococcus habitat is the human nasopharynx mucosa with a prevalence of about $40 \%$ in infants and $15 \%$ in adults ${ }^{7}$. The bacterium is transferred among people by coughing and sneezing. It has to face the natural barrier, the host's immune system and up to 700 different microbial species that can colonize the same niche ${ }^{8,9}$. S. pneumoniae colonizes the nasopharynx by degradation of the mucus by exoglycosidases such as neuraminidase A, $\beta$-galactosidase, $\beta$-N-acetylglucosaminidase, and neuraminidase B decreasing mucus viscosity ${ }^{10}$. S. pneumoniae produces the pneumolysin that is a major exotoxin. It decreases epithelial cell ciliary's beating and enhances bacterial adherence ${ }^{11}$. Pneumococcus also expresses the enzymes peptidoglycan, N-acetylglucosaminedeacetylase $\mathrm{A}$, and $\mathrm{O}$-acetyltransferase that provides resistance to lysozyme ${ }^{12}$ and it also produces IgA1 protease, which cleaves IgA, the major class of Ig in secretions, promoting binding to the respiratory mucosa ${ }^{13} . S$. pneumoniae may transmigrate through the epithelial cells by binding the phosphorylcholine with the receptor of the platelet-activating factor (PAF) or by connecting the pneumococcal choline-binding protein with the epithelial polymeric immunoglobulin receptor, which transports the bacterium to the basal membrane of the host's epithelial cell and may lead to invasive illness ${ }^{8,14}$.

\section{CENTRAL NERVOUS SYSTEM BACTERIALINVASION}

The CNS protection is formed by bony skull, the leptomeninges, the blood-brain barrier (BBB) and blood-cerebrospinal fluid barrier ${ }^{15}$. The BBB is constituted of brain microvascular endothelial cells, astrocytes, and pericytes. It maintains the neural microenvironment by regulating the passage of molecules into and out of the brain, and preserves the brain from whatever microorganisms and toxins that comes from the blood ${ }^{16}$. The $S$. pneumoniae crosses the BBB and interacts with cell-wall phosphorylcholine, the platelet-activating-factor receptor and cross the $\mathrm{BBB}$ without any evidence of intercellular tight-junction disruption or detection of microorganism between cells through transcellular traversal mechanism ${ }^{16}$. It can also crosses intercellularly by disruption of the interepithelial tight junctions ${ }^{8}$. The pneumococcus replication within the subarachnoid space occur concurrently with the release of the bacterial products such as peptidoglycan, cell wall fragments that are highly immunogenic and may lead to an increased inflammatory response in the host ${ }^{15}$. S. pneumoniae is recognized by antigen-presenting cells binding to a pattern recognition receptors. The main pattern recognition receptors involved in initial pneumococcus sensing in the CNS are Tolllike 2 receptors (TRL-2 or CD282) that is recognized by peptidoglycans and lipoteichoic acids ${ }^{17}$, Toll-like 4 receptors (TRL-4 or CD284) that are recognized by exotoxin pneumolysin ${ }^{18}$ and the Toll-Like 9 receptors (TRL-9 or CD289), an intracellular pattern recognition receptor that is activated by $\mathrm{CpG}$ in bacterial DNA ${ }^{19}$. Family members of the NOD-like receptors (NLRs), which are intracellular, play essential roles on innate immunity by detecting intracellular pathogen-associated molecular patterns ${ }^{20}$. When they are activated, they induce the activation of nuclear factor kappa B (NF- $\mathrm{B}$ ) or mitogen-activated protein kinase (MAPK) pathways and inflammatory caspases ${ }^{21}$. TRL-2 and TRL-4 use a common intracellular adapter protein known as myeloid differentiation factor 88 (MyD88) ${ }^{8}$. MyD88 signals for NF- $\mathrm{KB}$ activation and subsequent up-regulation of pro-inflammatory mediators. MyD88-deficient mice displayed a markedly diminished inflammatory host response in the CNS, as an evidenced of the reduced CSF pleocytosis and expression of cytokines, chemokines and complement factors ${ }^{22}$. Furthermore, MyD88-dependent immune response contributes to hearing loss in experimental pneumococcal meningitis; it is required for mounting a robust host immune response to $S$. pneumoniae in the $\mathrm{CNS}^{23}$. NF-кB comprises a closely related family to transcription factors, which play a key role on the expression of genes involved in the development of accessory cell and lymphocyte populations, expressing numerous proteins involved in inflammation and immune response ${ }^{24}$. It is also a transcriptional activator of many genes involved in the pathogenesis of pneumococcal meningitis, such as, TNF- $\alpha$, IL$1 \beta$, inducible nitric oxide synthase and intercellular adhesion molecules ${ }^{25,26}$ (Figure).

\section{INFLAMMATION}

\section{Cytokines}

Many brain cells such as astrocytes, glial cells, endothelial cells, ependymal cells, and resident macrophages can produce cytokines and pro-inflammatory molecules in response to bacterial replication and its components ${ }^{27}$. TNF- $\alpha$ is a 158 amino acid cytokine considered a pro-inflammatory molecule, enhancing the immune response to help speed-up the 
pathogens elimination and the resolution of the inflammatory challenge ${ }^{28}$. TNF- $\alpha$ leads to NF- $\kappa B$ activation in the CSF and brain resident cells, which regulates the expression of many pro-inflammatory mediators ${ }^{29}$. In animal models for pneumococcal meningitis, TNF- $\alpha$ was produced in the first $6 \mathrm{~h}$ of the immune response ${ }^{30}$. Intrathecal administration of TNF- $\alpha$ results in a similar pathophysiological characteristic of bacterial meningitis such as BBB disruption, facilitating bacterial traversal into the $\mathrm{CSF}^{31}$, on the other hand, TNF- $\alpha$ deficient mice increased mortality and spatial memory deficits ${ }^{32}$. TNF- $\alpha$ is a marker of the acute inflammatory response, however, it's also essential for an adequate host immune response ${ }^{8}$.

IL-1 $\beta$ is a pro-inflammatory cytokine, produced by perivascular, mononuclear phagocytes, glial cells, and meningeal macrophages that increase the expression of nearly all other cytokines such as TNF- $\alpha$, IL-6, IFN- $\gamma$, and chemokines. IL-1 $\beta$ has potent stimulatory effects on granulocytes white cells; it promotes the adhesion of neutrophils and monocytes in endothelial cells ${ }^{33}$. IL-1 $\beta$ is found in the CSF of patients with bacterial meningitis ${ }^{34}$, furthermore, in animal models it was produced in the first $24 \mathrm{~h}$ after pneumococcal meningitis induction $^{30}$, although intrathecal administration of IL-1 $\beta$ did not lead to CSF pleocytosis or brain edema ${ }^{35}$. However, the mortality was significantly higher and earlier in the course of the disease among $\mathrm{IL}-1$ receptor (IL-1R) gene-deficient mice, demonstrating that endogenous IL- $1 \beta$ is required for an adequate host defense in pneumococcal meningitis ${ }^{36}$.

IL-6 is produced by monocytes, endothelial cells, and astrocytes primarily in response to IL-1 $\beta^{37}$. It has predominantly pro-inflammatory effects such as potent inducer of acutephase proteins, fever and leukocytes ${ }^{38}$ but it also acts as an anti-inflammatory cytokine, indeed, the lack of IL-6 enhances inflammatory response but decreases vascular permeability in bacterial meningitis ${ }^{39}$. IL-6 gene-deficient mice showed impaired defense against pneumococcal pneumonia ${ }^{40}$.

IL-10 is a potent immunosuppressive cytokine, produced by monocytes, macrophages, $\mathrm{B}$ and $\mathrm{T}$ lymphocytes, brain cells such as neurons and microglia ${ }^{41}$. Elevated levels have been found in the CSF in patients with bacterial meningitis ${ }^{42}$, it leads to macrophage and monocyte deactivation and inhibits the cytokines production such as TNF- $\alpha$ and IL- 6 and the release of reactive oxygen species ${ }^{43}$. IL-10 gene-deficient mice were associated with higher levels of TNF- $\alpha$ and IL-6 in animal model of pneumococcal meningitis ${ }^{36}$.

TGF- $\beta$ is an anti-inflammatory cytokine that is expressed in neurons and glial cells, maintains $\mathrm{T}$ cell tolerance to self or innocuous environmental antigens via its direct effects on the differentiation, homeostasis and regulatory $\mathrm{T}$ cells ${ }^{44}$. It suppresses the production of IL-1 $\beta$, IL- 6 and TNF- $\alpha$ from microglia in vitro ${ }^{45}$, moreover, endogenous TGF- $\beta$ suppresses the host defense in the CSF of mice with $S$. pneumoniae meningitis $^{3}$. The collective activity of TGF- $\beta$ and IL-10 ensures a controlled inflammatory response specifically targeting

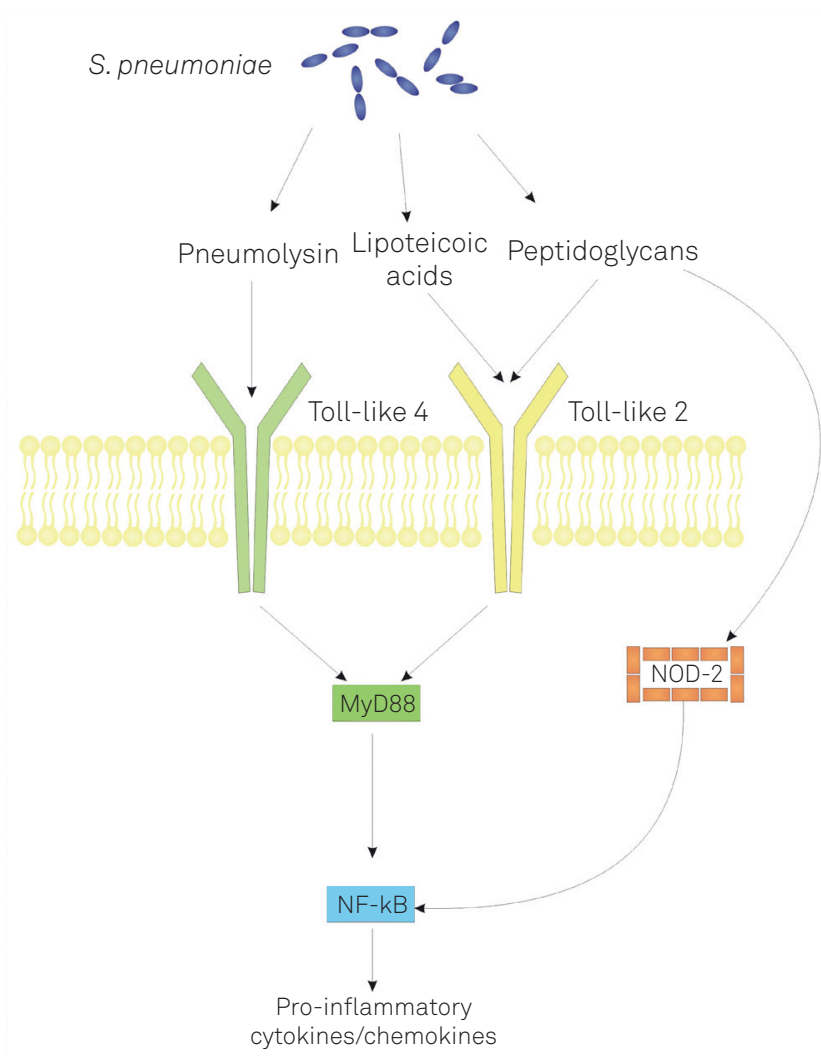

Figure. Summary of the development of host pattern recognition receptors involved in sensing S. pneumoniae. Tolllike 2 is activated by pneumococcal cell wall peptidoglycan, lipoteichoic acids and Toll-like- 4 is activated by pneumolysin, both use a common intracellular adapter protein MyD88 to

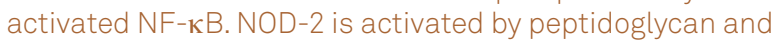
also activated NF- $\kappa \mathrm{B}$, inducing transcription of several proinflammatory mediators.

pathogens without evoking excessive immunopathology to the self-tissues ${ }^{44}$.

Chemokines are chemoattractant cytokines, which play key roles on the accumulation of inflammatory cells in the inflammation site. Increased chemokines levels have been reported in the CSF of patients with bacterial meningitis. IL-8 is produced by wide variety cell types such as monocytes, macrophages through stimuli of the live bacteria, TNF- $\alpha$, and IL- $\beta$. It is important to regulate the acute inflammatory response and it's rapidly synthesized in the inflammation sites with the function to recruit acute inflammatory cells ${ }^{46}$. In pneumococcal meningitis treatment with a monoclonal antibody to IL-8 given intravenously attenuated the pleocytosis in rabbits. IL-8 plays an important role on the recruitment of neutrophils during experimental pneumococcal meningitis ${ }^{47}$.

\section{Matrix metalloproteinases}

Matrix metalloproteinases (MMPs) is a family $\mathrm{Zn}^{2+}$ and $\mathrm{Ca}^{2+}$ dependent endopeptidases, which is secreted by all cell types in the CNS and serve as effectors of cell migration, tissue remodeling, degrade constituents of the $\mathrm{BBB}$ 
and interacts with the cytokines ${ }^{48}$. Gelatinases (MMP-2 and MMP-9) have shown to induce BBB breakdown and facilitate leukocyte extravasation in experimental bacterial meningitis ${ }^{49}$, furthermore, patients with bacterial meningitis present high concentrations of MMP-939 and MMP-8 in the CSF, indeed, high concentrations of MMP-9 were correlated with risk factor for the development of postmeningitis neurological sequelae ${ }^{48}$. In a rat model, adjuvant treatment with dexamethasone resulted in a lower MMP-9 mRNA ${ }^{50}$, in addition, combining the MMP and TNF- $\alpha$ inhibitors led to a decrease incidence of the seizures and mortality, furthermore, neuronal necrosis in the cortex and apoptosis in the hippocampus were attenuated in rats submitted by pneumococcal meningitis ${ }^{51}$.

\section{Oxidative stress}

Bacterial components are recognized by Toll-like receptors or other pathogen recognition receptors that lead to the activation of NF- $\mathrm{KB}^{21}$. It triggers the expression of pro-inflammatory cytokines, as consequence, polymorphonuclear are attracted, activated and released in large amounts superoxide anion $\left(\mathrm{O}_{2}^{-}\right)$and nitric oxide (NO), leading to the peroxynitrite formation $\left(\mathrm{ONOO}^{-}\right)^{52}$. The release of large amounts of reactive nitrogen species (RNS) and reactive oxygen species (ROS) had been documented in patient's populations, likewise, in animal model by pneumococcal meningitis and might contribute to the development of neuronal damage ${ }^{52}$. Treatment with superoxide dismutase mimetics and catalase (hydrogen peroxide scavenger) inhibited brain edema formation ${ }^{53,54}$; antibiotic therapy prevented, in part, the oxidative stress in experimental pneumococcal meningitis ${ }^{55}$. Brain resident cells produce $\mathrm{O}_{2}^{-}, \mathrm{H}_{2} \mathrm{O}_{2}$ as part of the host immune response to invasive bacterial infection, in addition, $S$. pneumoniae itself is also an important source of $\mathrm{H}_{2} \mathrm{O}_{2}$, which is not only able to cause direct cytotoxic damage but also reacts with the host's $\mathrm{NO}$ to form the highly reactive species $\mathrm{ONOO}^{56}$. Peroxynitrite can crosses membranes, activate the MMPs, leads to DNA damage, protein carbonylation and cause lipid peroxidation ${ }^{52}$, leading to a membrane integrity loss, energy depletion, contributing to cell injury during pneumococcal meningitis ${ }^{57}$.

\section{NEURONAL DAMAGE AND TARGETS FOR ADJUNCTIVE THERAPY}

Pneumococcal meningitis causes sequelae including sensory-motor deficits, hearing loss, deafness and neuro intellectual impairment, including deficits in learning and memory. These neurofunctional consequences occur in up to $30 \%$ of survivors patients ${ }^{5}$. The neuronal damage is caused by the strong inflammatory reaction and direct effects of the microorganism ${ }^{32}$. Significant injury during bacterial meningitis arises from mechanisms of neuronal apoptosis, particularly in the hippocampus; in autopsies cases of bacterial meningitis were found apoptosis of neurons in the dentate gyrus ${ }^{58}$. Apoptosis can involve both the caspasedependent and the caspase-independent pathway ${ }^{59}$. The caspase-independent pathway is triggered by the pneumolysin and $\mathrm{H}_{2} \mathrm{O}_{2}$ that are produced by $S$. pneumoniae. The actions of these toxins result in an increase in ROS and calcium, resulting in mitochondrial dysfunction that leads to the release of apoptosis-inducing factor into the cytosol ${ }^{56,59}$. However, the caspase-dependent pathway occurs later, and pneumococcal cell-wall components trigger the required host inflammatory response from the leukocytes. p53 tumor suppressor protein and ATM protein kinase (ATM) as upstream mediators that converge on the mitochondria to initiate the release of cytochrome $\mathrm{c}$, which is necessary to form the apoptosome forming apoptotic protease activating factor-1 (Apaf-1) and active caspase-9 that results in the activation of caspase-359.

In the pre-antibiotic era when acute bacterial meningitis was described the mortality rate was from 90 to $100 \%$. Although, nowadays, with the development of highly effective antibiotics, more precocity in diagnosis with precise diagnostic methods as immunological and molecular biology methods, supportive care in intensive care units the mortality doesn't decrease. The mortality of S. pneumoniae is (16-37\%), N. meningitidis (5\%), Haemophilus influenzae (3\%). This maintenance of mortality is explained by inflammation in the subarachnoid space caused by the generation of bacterial cell wall components in CSF during treatment of meningitis with antibiotics ${ }^{2,60,61}$. Bacterial cell wall components stimulate the release of inflammatory cytokines in the CNS such as TNF- $\alpha$, IL- $1 \beta$, and prostaglandins.

Possible therapeutic approaches to decrease the harmful effects of TNF and/or IL-1- $\beta$ are investigated in vitro and animal model and might include: a) Drugs or procedures to decrease their production, block their biologic activity or enhance removal from the circulation; b) Passive immunization with antibodies against TNF and IL-1, limitation is the BBB even during inflammation; c). Drugs that interfere with IL-1 induced arachidonic acid metabolites.

Corticosteroids are largely used as adjunctive therapy for acute bacterial meningitis since the 90 decade.

In addition to corticosteroids, several other adjunctive approaches may be useful (Table) ${ }^{60-67}$; although there is no proved clinical evidence for use of these therapies and some are only experimental. The use of bactericidal but nonbacteriolitic antibiotics to reduce endotoxin and other injurious substance release into CSF as rifampicin and daptomycin have been investigated in animal models of pneumococcal meningitis ${ }^{63}$. Thalidomide acts by blocking TNF release from microglia ${ }^{65}$. An enhanced lifespan of activated neutrophils in the CSF contributes to massive leukocyte accumulation and host-driven cytotoxicity. Roscovitine, a purine derivative 
that induces apoptosis in neutrophils, is studied in mouse models. TNF- $\alpha$ inhibitor decrease TNF- $\alpha$ levels and pleocytosis in $\mathrm{CSF}^{68}$, blocking IL-6 intravenously in a rat model of pneumococcal meningitis reduced also pleocytosis ${ }^{69}$ and TGF- $\beta 2$ administrated intraperitoneally reduced the subarachnoid inflammation in rats with pneumococcal meningitis ${ }^{54}$. Intracisternal administration of the caspase-3 inhibitor reduced apoptosis in the dentate gyrus hippocampal ${ }^{70}$ and blocking of caspase-1 demonstrated lower levels of IL-1 $\beta^{71}$.

Corticosteroids are highly effective in reducing IL- $1 \beta$ production in vitro and in vivo. A meta-analysis that included all double-blinded, randomized, placebo-controlled trials since 2001 that evaluated dexamethasone in bacterial meningitis concluded that adjunctive dexamethasone in bacterial meningitis may reduce mortality and hearing loss for patients in developing countries. There may be no benefit for individuals in developing nations with a high prevalence of HIV infection $^{66}$. The intravenous dose of dexamethasone proposed is $2 \times 0.4 \mathrm{mg} / \mathrm{kg} / 24 \mathrm{~h}$ or $4 \times 8-12 \mathrm{mg} / 24 \mathrm{~h}$, during 48 to 96 hours. The first dose was delivered prior or concomitantly with the first dose of parenteral antibiotic ${ }^{67}$. In previous studies we verified dexamethasone treatment reverses cognitive impairment but increases brain oxidative stress in rats submitted to pneumococcal meningitis ${ }^{72}$. Adjunctive dexamethasone in bacterial meningitis reduces mortality and hearing loss for patients but still needs more evaluation.
Table. Adjunctive therapy for acute bacterial meningitis.

Corticosteroids

Nonbacteriolytic antibiotics

Nosteroidal anti-inflammatory agents

Prostaglandin inhibitors

Anti-endotoxin-biding agents

Monoclonal antibodies directed against endotoxin, cytokines or

leukocyte-endothelium adhesion molecules

Pentoxifylline

Cytokine antagonists

NOS inhibitors

Thalidomide

Osmotic dehydrating agents (manitol, glycerol)

Scavengers of peroxynitrite

MMPs Inhibitors

Adenosine $A_{2 A}$ receptors agonists

Reducing lifespan of neutrophils

NOS: nitric oxid synthases; MMPs: matrix metalloproteinases.

\section{FINAL REMARKS}

Despite the significant advances in treatment, pneumococcal meningitis remains one of the most important infectious diseases of the CNS with high mortality and morbidity. Experimental animal model with its limitations continues to provide the understanding of this complex pathophysiology disease and propose new therapies adjunctive.

\section{References}

1. van de Beek D, de Gans J, Spanjaard L, Weisfelt M, Reitsma JB, Vermeulen M. Clinical features and prognostic factors in adults with bacterial meningitis. N Eng J Med 2004;351:1849-1859.

2. Weisfeld M, de Gans J, van der Poll T, van de Beek D. Pneumococcal meningitis in adults: new approaches to management and prevention. Lancet Neurol 2006;5:332-342.

3. Malipiero U, Koedel U, Pfister HW, et al. TGF-beta receptor II gene deletion in leucocytes prevents cerebral vasculitis in bacterial meningitis. Brain 2006;129 Pt 9:2404-2415.

4. Brasil. Ministério da Saúde. Portal da saúde. [cited 2011 Dec 12]. Available from: http://portalsaude.saude.gov.br/portalsaude/ index.cfm

5. Hoogman M, van de Beek D, Weisfelt M, Gans J, Schmand B. Cognitive outcome in adults after bacterial meningitis. J Neurol Neurosurg Psychiatry 2007;78:1092-1096.

6. Grimwood K, Anderson P, Anderson V, Tan L, Nolan T.. Twelve year outcomes following bacterial meningitis: further evidence for persisting effects. Arch Dis Child 2000;83:111-116.

7. Brugger SD, Hathaway LJ, Mühlemann K. Detection of Streptococcus pneumoniae strain colonization in the nasopharynx. J Clin Microbiol 2009;47:1750-1756.

8. Mook-Kanamori BB, Geldhoff M, van der Poll T, van de Beek D. Pathogenesis and pathophysiology of pneumococcal meningitis. Clin Microbiol Rev 2011;24:557-591.

9. Aas JA, Paster BJ, Stokes LN, Olsen I, Dewhirst FE. Defining the normal bacterial flora of the oral cavity. J Clin Microbiol 2005;43:5721-5732.

10. Burnaugh AM, Frantz LJ, King SJ. Growth of Streptococcus pneumoniae on human glycoconjugates is dependent upon the sequential activity of bacterial exoglycosidases. J Bacteriol 2008;190:221-230.
11. Feldman C, Mitchell TJ, Andrew PW, et al. The effect of Streptococcus pneumoniae pneumolysin on human respiratory epithelium in vitro. Microb Pathog 1990;9:275-284.

12. Davis K,AkinbiH,Standish A, WeiserJ.Resistance to mucosal lysozyme compensates for the fitness deficit of peptidoglycan modifications by Streptococcus pneumoniae. PLoS Pathog 2008;4:e1000241.

13. Weiser JN, Bae D, Fasching C, Scamurra RW, Ratner AJ, Janoff EN. Antibody-enhanced pneumococcal adherence requires IgA1 protease. Proc Natl Acad Sci U S A 2003;100:4215-4220.

14. Cundell DR, Gerard NP, Gerard C, Idanpaan-Heikkila I, Tuomanen EI. Streptococcus pneumoniae anchor to activate human cells by the receptor for platelet-activating factor. Nature 1995;377:435-438.

15. Sellner J, Täuber MG, Leib SL. Pathogenesis and pathophysiology of bacterial CNS infections. Handb Clin Neurol 2010;96:1-16.

16. Kim KS. Mechanisms of microbial traversal of the blood-brain barrier. Nat Rev Microbiol 2008;6:625-634.

17. Schröder NW, Morath S, Alexander C, et al. Lipoteichoic acid (LTA) of Streptococcus pneumoniae and Staphylococcus aureus activates immune cells via Toll-like receptor (TLR)-2, lipopolysaccharidebinding protein (LBP), and CD14, whereas TLR-4 and MD-2 are not involved. J Biol Chem 2003;278:15587-15594.

18. Malley R, Henneke P, Morse SC, et al. Recognition of pneumolysin by Toll-like receptor 4 confers resistance to pneumococcal infection. Proc Natl Acad Sci U S A 2003;100:1966-1971.

19. Hemmi H, Takeuchi O, Kawai T, et al. A Toll-like receptor recognizes bacterial DNA. Nature 2000;408:740-745.

20. Kersse K, Bertrand MJ, Lamkanfi M, Vandenabeele P. NOD-like receptors and the innate immune system: coping with danger, damage and death. Cytokine Growth Factor Rev 2011;22:257-276. 
21. Opitz B, Eitel J, Meixenberger K, Suttorp N. Role of Toll-like receptors, NOD-like receptors and RIG-I-like receptors in endothelial cells and systemic infections. Thromb Haemost 2009;102:1103-1109.

22. Koedel $U$, Rupprecht T, Angele B, et al. MyD88 is required for mounting a robust host immune response to Streptococcus pneumoniae in the CNS. Brain 2004;127:1437-1445.

23. Klein M, Schmidt C, Kastenbauer S, et al. My D88 dependent immune response contributes to hearing loss in experimental pneumococcal meningitis. J Infect Dis 2007;195:1189-1193.

24. Tato CM, Hunter CA. Host-pathogen interactions: subversion and utilization of the NF-kappa B pathway during infection. Infect Immun 2002;70:3311-3317.

25. Koedel U, Bayerlei I, Paul R, Sporer B, Pfister HW. Pharmacologic interference with NF-kappaB activation attenuates central nervous system complication in experimental pneumococcal meningitis. J Infect Dis 2000;182:1437-1445.

26. Kastenbauer S, Koedel U, Weih F, Ziegler-Heitbrock L, Pfister HW. Protective role of NF-kappaB1 (p50) in experimental pneumococcal meningitis. Eur J Pharmacol 2004;498:315-318.

27. Moreillon P, Majcherczyk PA. Proinflammatory activity of cellwall constituents from gram-positive bacteria. Scand J Infect Dis 2003;35:632-641.

28. Kronfol Z, Remick D. Cytokines and the brain: implications for clinical psychiatry. Am J Psychiatry 2000;157:683-694

29. Ichiyama T, Isumi H, Yoshitomi T, Nishikawa M, Matsubara T, Furukawa S. NF-kappaB activation in cerebrospinal fluid cells from patients with meningitis. Neurol Res 2002;24:709-712.

30. Barichello T, dos Santos I, Savi GD, et al. TNF-alpha, IL-1 beta, IL-6, and cinc-1 levels in rat brain after meningitis induced by Streptococcus pneumoniae. J Neuroimmunol 2010;221:42-45.

31. Rosenberg GA, Estrada EY, Dencoff JE, Stetler-Stevenson WG. Tumor necrosis factor-alpha-induced gelatinase B causes delayed opening of the blood-brain barrier: an expanded therapeutic window. Brain Res1995;703:151-155.

32. Gerber J, Böttcher T, Hahn M, Siemer A, Bunkowski S, Nau R. Increased mortality and spatial memory deficits in TNF-alpha-deficient mice in ceftriaxone-treated experimental pneumococcal meningitis. Neurobiol Dis 2004;16:133-138.

33. Dinarello CA. Interleukin-1 $\beta$. Crit Care Med 2005;33 12 Suppl:S460-S462.

34. Østergaard C, Brandt C, Konradsen HB Samuelsson S. Differences in survival, brain damage, and cerebrospinal fluid cytokine kinetics due to meningitis caused by 3 different Streptococcus pneumoniae serotypes: evaluation in humans and in 2 experimental models. J Infect Dis 2004:190:1212-1220.

35. Saukkonen K, Sande S, Cioffe C, et al. The role of cytokines in the generation of inflammation and tissue damage in experimental grampositive meningitis. J Exp Med 1990;171:439-448.

36. Zwijnenburg PJ, van der Poll T, Florquin S, Roord JJ, van Furth AM. Interleukin-10 negatively regulates local cytokine and chemokine production but does not influence antibacterial host defense during murine pneumococcal meningitis. Infect Immun 2003;71:2276-2279.

37. Rusconi F, Parizzi F, Garlaschi L, et al Interleukin 6 activity in infants and children with bacterial meningitis. The Collaborative Study on Meningitis. Pediatr Infect Dis J 1991;10:117-121.

38. GruolDL, Nelson TE.Physiological and pathological roles of interleukin-6 in the central nervous system. Mol Neurobiol 1997;15:307-339.

39. Paul R, Koedel U, Winkler F, et al. Lack of IL-6 augments inflammatory response but decreases vascular permeability in bacterial meningitis. Brain 2003;126 Pt 8:1873-1882.

40. van der Poll T, Keogh C, Guirao X, Buurman W, Kopf M, Lowry S. Interleukin-6 gene-deficient mice show impaired defense against pneumococcal pneumonia.J Infect Dis 1997;176:439-444.

41. Howard M, O'Garra A. Biological properties of interleukin 10. Immunol Today 1992;13:198-200.
42. Kornelisse RF, Savelkoul HF, Mulder PH, et al. Interleukin-10 and soluble tumor necrosis factor receptors in cerebrospinal fluid of children with bacterial meningitis. J Infect Dis 1996;173:1498-1502.

43. Koedel U, Bernatowicz A, Frei K, Fontana A, Pfister HW. Systemically (but not intrathecally) administered IL-10 attenuates pathophysiologic alterations in experimental pneumococcal meningitis. J. Immunol 1996;157:5185-5191.

44. Li MO, Flavell RA. Contextual regulation of inflammation: a duet by transforming growth factor-beta and interleukin-10. Immunity 2008;28:468-476

45. Suzumura A, Sawada M, Yamamoto H, Marunouchi T. Transforming growth factor-beta suppresses activation and proliferation of microglia in vitro. J Immunol 1993;151:2150-2158.

46. Remick DG. Interleukin-8. Crit Care Med 2005;33(Suppl 12): S466-S467.

47. Østergaard C, Yieng-Kow RV, Benfield T, Frimodt-Møller N, Espersen F, Lundgren JD. Inhibition of leukocyte entry into the brain by the selectin blocker fucoidin decreases interleukin-1 (IL-1) levels but increases IL-8 levels in cerebrospinal fluid during experimental pneumococcal meningitis in rabbits. Infect Immun 2000;68:3153-3157.

48. Leppert D, Leib SL, Grygar C, Miller KM, Schaad UB, Holländer GA. Matrix metalloproteinase (MMP)-8 and MMP-9 in cerebrospinal fluid during bacterial meningitis: association with blood-brain barrier damage and neurological sequelae. Clin Infect Dis 2000;31:80-84.

49. Rosenberg GA, Kornfeld M, Estrada E, Kelley RO, Liotta LA, StetlerStevenson WG. TIMP-2 reduces proteolytic opening of blood-brain barrier by type IV collagenase. Brain Res 1992; 576:203-207.

50. Liu X, Han Q, Sun R, Li Z. Dexamethasone regulation of matrix metalloproteinase expression in experimental pneumococcal meningitis. Brain Res 2008;1207:237-243.

51. Leib SL, Clements JM, Lindberg RL, et al. Inhibition of matrix metalloproteinases and tumor necrosis factor alpha converting enzyme as adjuvant therapy in pneumococcal meningitis. Brain 2001;124 Pt 9:1734-1742

52. Klein M, Koedel U, Pfister HM. Oxidative stress in pneumococcal meningitis: a future target for adjunctive therapy? Prog Neurobiol 2006;80:269-280

53. Pfister HW, Koedel U, Dirnagl U, Haberl RL, Leiden W, Einhäupl KM. Superoxide dismutase inhibits brain oedema formation in experimental pneumococcal meningitis. Acta Neurochir Supll (Wien) 1990;51:378-380

54. Pfister HW, Ködel U, Dirnagl U, Haberl RL, Ruckdeschel G, Einhaupl KM Effect of catalase on regional cerebral blood flow and brain edema during the early phase of experimental pneumococcal meningitis. $J$ Infect Dis 1992;166:1442-1445.

55. Barichello T, Savi GD, Silva GZ et al. Antibiotic therapy prevents, in part, the oxidative stress in the rat brain after meningitis induced by Streptococcus pneumoniae. Neurosci Lett 2010;478:93-96.

56. Braun JS, Sublett JE, Freyer D, et al Pneumococcal pneumolysin and $\mathrm{H}_{2} \mathrm{O}_{2}$ mediate brain cell apoptosis during meningitis. $J$ Clin Invest 2002;109:19-27

57. Scheld WM, Koedel U, Nathan B, Pfister HW. Pathophysiology of bacterial meningitis: mechanism(s) of neuronal injury. J Infect Dis 2002;186 (Suppl 2): S225-S233

58. Nau R, Soto A, Brück W. Apoptosis of neurons in the dentate gyrus in humans suffering from bacterial meningitis. J Neuropathol Exp Neurol 1999;58:265-274.

59. Mitchell L, Smith SH, Braun JS, Herzog KH, Weber JR, Tuomanen EI. Dual phases of apoptosis in pneumococcal meningitis. J Infect Dis 2004:190:2039-2046

60. Kastenbauer S, Pfister HW. Pneumococcal meningitis in adults: spectrum of complications and prognostic factors in a series of 87 cases. Brain 2003;126 Pt 5:1015-1025.

61. Østergaard C, Konradsen HB, Samuelsson S. Clinical presentation and prognostic factors of Streptococcus pneumoniae meningitis according to the focus of infection. BMC Infect Dis 2005;5:93. 
62. Pelkonen T, Roine I, Cruzeiro ML, Pitkaranta A, Kataja M, Peltola H. Slow initial $\beta$-lactam infusion and oral paracetamol to treat childhood bacterial meningitis: a randomized controlled trial. Lancet Infect Dis 2011;11:613-621

63. Koedel U, Klein M, Pfister HW. Modulation of brain injury as a target of adjunctive therapy in bacterial meningitis. Curr Infect Dis Rep 2010;12:266-273.

64. Tunkel AR. Bacterial meningitis non-antibiotic modes of therapy. Curr Opin Infect Dis 1993;6:638-643.

65. Peterson PK,HuS, ShengWS, etal. Thalidomide inhibits tumor necrosis factor $\alpha$ production by lipopolysaccharide- and lipoarabinomannanstimulated human microbial cells. J Infect Dis 1995;172:1137-1140.

66. Cooper DD, Seupaul RA. Is adjunctive dexamethasone beneficial in patients with bacterial meningitis? Ann Emerg Med 2012; 59:225-226.

67. Peterkovic V,Trkulja V, Kutlesa M, Krajinovic V, Lepur D. Dexamethasone for adult community-acquired bacterial meningitis: 20 years of experience in daily practice. J Nerol 2012;259:225-236.
68. Burroughs MH, Tsenova-Berkova L, Sokol K, Ossig J, Tuomanen E, Kaplan G. Effect of thalidomide on the inflammatory response in cerebrospinal fluid in experimental bacterial meningitis. Microb Pathog 1995;19:245-255.

69. Marby D, Lockrart GR, Raymond R, Linakis JG. Anti interleukin-6 antibodies attenuate inflammation in a rat meningitis model. Acad Emerg Med 2001;8:946-949.

70. Gianinazzi C, Grandgirard D, Imboden H, et al. Caspase-3 mediates hippocampal apoptosis in pneumococcal meningitis. Acta Neuropathol 2003;105:499-507.

71. Koedel U, Winkler F, Angele B, Fontana A, Flavell RA, Pfister HW. Role of Caspase-1 in experimental pneumococcal meningitis: Evidence from pharmacologic Caspase inhibition and Caspase-1-deficient mice. Ann Neurol 2002;51:319-329.

72. Barichello T, Santos ALB, Silvestre C, et al. Dexamethasone treatment reverses cognitive impairment but increases brain oxidative stress in rats submitted to pneumococcal meningitis. Oxid Med Cell Longev 2011; 2011:173035. 